\title{
Correction: The Bayesian brain and cooperative communication in schizophrenia
}

Cite as: J Psychiatry Neurosci 2022 February 17; 47(1). doi: 10.1503/jpn.220020

In the editorial published on Feb. 8, 2022, ${ }^{1}$ Figure 1 contained an error. The vertical box on the left should have read "Hierarchical generation of predictions."

This has been corrected at jpn.ca

\section{Reference}

1. Palaniyappan L, Venkatasubramanian G. The Bayesian brain and cooperative communication in schizophrenia. J Psychiatry Neurosci 2022;47:E48-54.

Content licence: This is an Open Access article distributed in accordance with the terms of the Creative Commons Attribution (CC BY-NC-ND 4.0) licence, which permits use, distribution and reproduction in any medium, provided that the original publication is properly cited, the use is noncommercial (i.e., research or educational use), and no modifications or adaptations are made. See: https: / / creativecommons.org/licenses/by-nc-nd/4.0/ 